\title{
Comparison of Interferon-Gamma (IFNG) +874 T/A Single Nucleotide Polymorphism in Hepatitis C Virus Infected Patients and Non-Infected Controls in Mashhad, Iran
}

\author{
Sina Rostami ${ }^{1}$, Alireza Pasdar ${ }^{2,3}$, Sina Gerayli ${ }^{4}$, Hamed Hatami ${ }^{5}$, Samaneh Sepahi ${ }^{6}$, Fatemeh Nategh ${ }^{7}$, \\ Mojtaba Meshkat ${ }^{8}$, Seyed Mousalreza Hoseini ${ }^{9}$, Mitra Ahadi ${ }^{9}$, Hamid Reza Sima ${ }^{10}$, Hasan Vosughinia ${ }^{10}$, \\ Mohammad Reza Sarvghad ${ }^{11}$, Abbas Esmaeelzade', Hosein Nomani' ${ }^{12}$, Homan Mosanan Mozafari ${ }^{9}$, \\ Fariba Rezai Talab ${ }^{10}$, Mohammad Taghi Shakeri' ${ }^{13}$, Zahra Meshkat ${ }^{12}$
}

1. Dept. of Laboratory Medicine, Children's and Women's Health, NTNU - Norwegian University of Science and Technology, NO-7491 Trondheim, Norway

2. Dept. of Modern Sciences and Technologies, Faculty of Medicine, Mashhad University of Medical Sciences, Mashhad, Iran

3. Division of Applied Medicine, Medical School, University of Aberdeen, Foresterhill, Aberdeen, AB25 2ZD, UK

4. Dept. of Biology, University of Western Ontario, London, Ontario N6A5BF, Canada

5. Dept. of Immunology, School of Medicine, Mashhad University of Medical Sciences, Mashhad, Iran

6. Targeted Drug Delivery Research Centre, School of Pharmacy, Mashhad University of Medical Sciences, Mashhad, Iran 7. Applied Biotechnology Research Center, Tehran Medical Sciences Branch, Islamic Azad University, Tehran, Iran

8. Islamic Azad University, Mashhad Branch, Mashhad, Iran

9. Dept. of Internal Medicine, Qaem Hospital, Mashhad University of Medical Sciences, Mashhad, Iran

10. Dept. of Internal Medicine, Imam Reza Hospital, Mashhad University of Medical Sciences, Mashhad, Iran

11. Dept. of Infectious Diseases, Imam Reza Hospital, Mashhad University of Medical Sciences, Mashhad, Iran

12. Antimicrobial Resistance Research Center, Mashhad University of Medical Sciences, Mashhad, Iran

13. Dept. of Biostatistics, Public Health School, Mashhad University of Medical Sciences, Mashhad, Iran

\section{KEYWORDS}

Interferon-gamma

Single Nucleotide

Polymorphism

Hepatitis $\mathrm{C}$ virus

Article Info

Received 20 Jul 2016;

Accepted 29 Dec 2016;

Published Online31 May 2017;

\section{ABSTRACT}

Background and Objectives: Interferon-gamma is an important cytokine, which facilitates immunity against intracellular pathogens. Several factors, including genetic variations of cytokine-producing genes have been shown to influence the progression and severity of Hepatitis $\mathrm{C}$ virus (HCV) infection.

Methods: Between January and December 2012, 87 HCV-infected individuals and 89 individuals without $\mathrm{HCV}$ infection were recruited for the study of Single Nucleotide Polymorphism (SNP) at Interferon Gamma (IFNG) +874 T/A. After extraction of genomic DNA from Peripheral Blood Mononuclear Cells (PBMCs) in blood sample of the individuals, Amplification Refractory Mutation System (ARMS) polymerase chain reaction was performed to evaluate the SNP at this position.

Results: The frequency of genotype TA was $62.1 \%$ in the HCV-infected group, while it was $47.2 \%$ for the control group ( $p=0.033$ ). However, after adjusting for confounders (including alcohol consumption, drug addiction, transfusion, and tattoos), the genotypes at this position did not show any statistically significant association with HCV infection (adjusted $\mathrm{P}$ values were above 0.05 ). The frequency of allele A was slightly higher in patients than the controls $(55.2 \%$ versus $48.3 \%$ ).Carriers of A allele were more frequent in patients with $\mathrm{HCV}$ infection compared to the control group $(55.17 \%$ in patients versus $48.31 \%$ in the control group; $\mathrm{P}=0.02)$. However, after adjustment for confounders, the results were no longer statistically significant $(\mathrm{P}=0.2)$.

Conclusion: A carrier status for certain alleles and genotypes at Interferon Gamma $(I F N G)+874$ T/A may lead to higher susceptibility to HCV infection in a certain population.

Correspondence information: Zahra Meshkat (PhD), Associate Professor, P.O Box 155, Antimicrobial Resistance Research Center, Mashhad University of Medical Sciences, 9196773117 Mashhad, IR Iran, Tel: +98-51- 38012453, Fax: +98-51-38002287, Email: meshkatz@mums.ac.ir

Copyright $\odot$ 2017, IRANIAN JOURNAL OF PATHOLOGY. This is an open-access article distributed under the terms of the Creative Commons Attribution-noncommercial 4.0 International License which permits copy and redistribute the material just in noncommercial usages, provided the original work is properly cited. 


\section{Introduction}

Chronic infection with Hepatitis C Virus (HCV) may lead to complications such as fibrosis, cirrhosis, and Hepatocellular Carcinoma (HCC). Half a million new cases of liver cancer have been estimated, annually, $22 \%$ of which are caused by infection with HCV (1). Worldwide, about 130 to 170 million individuals are infected with Hepatitis C Virus (HCV) (2).

Attempts to develop therapeutic vaccines against $\mathrm{HCV}$ infection have not so far been very successful as a result of variants of $\mathrm{HCV}$, which are capable of undergoing extensive mutations that confer them new resistance adaptations (3). An area that has received extensive attention during the recent decades is the study of host immunity and its interactions with infectious agents, rather than the previously more conventional approach of studying variations in infectious agents. It has been shown that chronic HCV effects the number, subset composition, and functional performance of immune cells, including natural killer cells, natural killer $\mathrm{T}$ cells, dendritic cells, macrophages, and $\mathrm{T}$ cell (4). Furthermore, genetic variations in host genes, which have a role in mediating immunity, may affect the regulation and production of components required for the two arms of the immune system, namely innate and adaptive immunity. One of the important components is cytokines, which have immune regulatory roles and are secreted by the immune cells. Cytokines are capable of suppressing viral replication and mediating host immune responses (5). Cytokines may show different expression levels, while interactions with other components may affect the ability of the immune system to combat the infection and to reduce or eliminate the virus or its associated complications. An estimated 10 million Single Nucleotide Polymorphisms (SNPs) are assumed to be present in the human genome (6).It has been suggested that the rate of expression of some cytokines is influenced by mutations in their regulatory and coding regions. This, in turn, is considered to influence the natural history of $\mathrm{HCV}$ infection $(7,8)$.
One of the important cytokines involved in suppressing viral infections is Interferon Gamma $(I F N G)$, which has clinical implications in preventing the development of chronic hepatitis, liver cirrhosis, and hepatocellular carcinoma (9). The IFNG gene is present on chromosome12q24.1. Interferon Gamma-induced signaling pathways involved in the activation of genes with antiviral properties are very complicated (10). The signaling pathway is partly controlled by the Ras-MAPK and Jak-STAT pathways $(11,12)$. Antiviral properties of $I F N G$ are mediated through the induction of gene expression for double-stranded RNA activated Protein Kinase (PKR), 2'-5' oligoadenylate synthetase, and dsRNA-specific adenosine deaminase (13). In addition to its role as an antiviral agent, IFNG is capable of engaging T cells to the site of inflammation $(14,15)$. The IFNG produced by $\mathrm{T}$ and Natural Killer (NK) cells can mediate the function of T helper cell type 1 (Th1) (16)

The SNP at Interferon Gamma $($ IFNG $)+874$ T/A of the human Interferon-Gammais present at the 5' end of the first intron. Polymorphisms normally appear in regulatory regions and their role in certain diseases has been previously investigated. Among these polymorphisms, intron $1+874 \mathrm{~T} / \mathrm{A}$ and $\mathrm{C} / \mathrm{A}$ repeat microsatellites and promoter SNP -179 T/G have been considered previously (17). Although some in vitro studies showed that IFNG can suppress the replication of HCV $(18,19)$, no correlation has been found regarding the expression level of IFN Gand HCV viral load $(20,21)$.

The current study was performed to evaluate the frequency of alleles and genotypes at position +874 of the IFNG gene between patients infected with $\mathrm{HCV}$ and individuals without $\mathrm{HCV}$ infection in the city of Mashhad, northeast of Iran, to determine if there is any association between a specific allele or genotype at this position and infection with chronic $\mathrm{HCV}$. 


\section{Materials and Methods}

\section{Population study and sample collection}

After receiving the approval from the ethical committee of Mashhad University of Medical Sciences, $87 \mathrm{HCV}$-infected patients and 89 healthy individuals were recruited from January to December 2012 for the study of single nucleotide polymorphism at IFNG +874T/A. Informed consents were obtained from the studied patient and controls. Blood samples were obtained at the Microbiology and Virology Research Center of Qaem hospital and outpatient clinic of Qaem hospital in Mashhad, Iran. Ten- and three-milliliter blood samples were obtained from patient and control groups, respectively. Blood samples were collected in tubes containing EDTA. Genomic DNA (for Amplification Refractory Mutation System (ARMS) Polymerase Chain Reaction (PCR)) was extracted from whole blood using a genomic DNA extraction Kit (GeNet Bio, Daejeon, Korea). Viral RNA was isolated from sera using QIAamp Viral RNA Mini Kit (Qiagen, USA). The control group was defined as individuals without $\mathrm{HCV}$ infection as determined by commercial
Enzyme Linked Immunosorbent Assay (ELISA) kits (Delaware Biotech, USA). Control subjects were screened for $\mathrm{HBV}$ and $\mathrm{HCV}$ markers by HBsAg and anti-HCV antibody ELISA kits (Delaware Biotech, USA). Hepatitis C Virusinfected patients were evaluated based on positive anti-HCV IgG test results as determined by a commercial ELISA kit (Delaware Biotech, USA), and HCV RNA, using Reverse Transcriptase (RT)PCR, as described previously (22). Hepatitis C Virus genotyping was performed using the method described by Ohno et al. (23). The HCV RNA load was evaluated using Gene Proof HCV real-time PCR Kit (Gene Proof a.s., Czech Republic) in accordance with the manufacturer's instructions. Three standard concentrations from $10^{2}$ to $10^{4}$ copy $/ \mathrm{mL}$ were made, and the real-time PCR was performed on Rotor Gene (Corbett Research, Australia). All known factors involved in the risk of $\mathrm{HCV}$ transmission, including yet not limited to a history of drug and alcohol addiction, transfusion, HIV infection, tattoos, working environments such as working in hospitals and family history of $\mathrm{HCV}$ infection, were recorded for the studied sample. A summary of demographic and risk factors are given in Table 1 .

Table 1. Information on demographic and risk factors in the studied population of HCV patients and control groups

\begin{tabular}{cccc|}
\hline Characteristics & Patients & Controls & P-Value \\
\hline Male: Female & $78: 9$ & $39: 50$ & $<0.05$ \\
\hline Age $($ years; mean \pm SD $)$ & $42.58+10.28$ & $36.33+12.72$ & $<0.05$ \\
\hline Addiction & $37(42.5 \%)$ & - & $<0.05$ \\
\hline Alcohol & $34(39.1 \%)$ & $2(2.2 \%)$ & $<0.05$ \\
\hline Transfusion & $31(35.6 \%)$ & $7(7.8 \%)$ & $<0.05$ \\
\hline Tattoo & $27(31.0 \%)$ & - & $<0.05$ \\
\hline ALT (U/L, mean \pm SD) & $36.42+30.59$ & $27+21.45$ & 0.06 \\
\hline Increased ALT* & $26(29.9 \%)$ & $19(21.35 \%)$ & $<0.05$ \\
\hline
\end{tabular}

*ALT, alanine aminotransferase with the unit U/L (unit per liter). * >41 U/L for men and >31 U/L for women.

\section{DNA extraction and genotyping}

Following extraction of DNA, ARMS PCR was performed. The primer sequences used for the amplification of IFNG+874T/A (238 bp in length) were as follows: $\mathrm{T}$ allele-specific primer, 5'TTCTTACAACACAAAATCAAATCT-3'; A allele-specific primer, 5'-TTCTTACAACACAAAATCAAATCA3' and reverse primer 5'-TCAACAAAGCTGATACTCCA3'. For PCR, the final reaction volume was $20 \mu \mathrm{L}$ including: 1X PCR buffer, 10 pmol forward and reverse primers, $10 \mathrm{mM} \mathrm{MgCl}_{2}, 1.5 \mathrm{mMdNTPs}$, and 0.5 unit Taq DNA polymerase (GeNetBio, Korea). The PCR program included initial denaturation at $96^{\circ} \mathrm{C}$ for 5 minutes and one cycle of $96^{\circ} \mathrm{C}$ for 130 seconds, $63^{\circ} \mathrm{C}$ for 60 seconds, and $72^{\circ} \mathrm{C}$ for 30 seconds; 9 cycles of $96^{\circ} \mathrm{C}$ for 10 seconds, $63^{\circ} \mathrm{C}$ for 60 seconds, and $72^{\circ} \mathrm{C}$ for 30 seconds, followed by 20 cycles of $96^{\circ} \mathrm{C}$ for 10 seconds, $60^{\circ} \mathrm{C}$ for 50 seconds and $72^{\circ} \mathrm{C}$ for 30 seconds. The PCR was followed by a final extension at $72^{\circ} \mathrm{C}$ for 5 minutes. Amplified PCR products were analyzed by $2.5 \%$ agarose gel stained with Green Viewer (Pars Tous, Iran). 


\section{Biochemical analysis}

Alanine aminotransferase levels were determined for the studied sample using Pars Azmoon Kit (Pars Azmoon, Iran) in accordance with the manufacturers' recommendations. A summary of the results of ALT is presented in Table 1. Alanine aminotransferase levels (determined at $37^{\circ} \mathrm{C}$ ) of $<31 \mathrm{U} / \mathrm{L}$ for females and $<41 \mathrm{U} / \mathrm{L}$ for males were reported as normal.

\section{Statistical analysis}

Chi-square and Fisher's exact test were used for qualitative comparison. Qualitative comparison was performed with $\mathrm{t}$ test. Logistic regression was used to compare the two groups. Data analysis was carried out using IBM SPSS software (IBM Corp., Armonk, NY) version 21 (24). P values below 0.05 were considered statistically significant.

\section{Results}

\section{Population study}

The mean age of the patients was $42.58 \pm 10.28$ years while that of the control group was $36.33 \pm$ 12.72 years. The age ranged from 16 to 66 years and 15 to 65 years in the patient and control groups, respectively. Also, among the patient group, 78 $(89.7 \%)$ were male and $9(10.3 \%)$ were female. While in the control group $39(43.8 \%)$ were male and $50(56.2 \%)$ were female (Table 1). The duration of treatment with interferon and ribavirin varied from one month to two years in patients with chronic HCV infection. The authors were not able to recruit more females in the patient group firstly because the above-mentioned high-risk behaviors were more commonly observed among males in the studied population and secondly because a lower number of females were willing to take part in the present study. Real-time PCR was used to evaluate HCV load for all participants in the patient group. The viral load results for nine patients are shown in Figure 1.

\section{Genetics study}

The agarose gel results of ARMS-PCR for several polymorphism statuses at IFNG $+874 \mathrm{~T} / \mathrm{A}$ is shown in Figure 2.

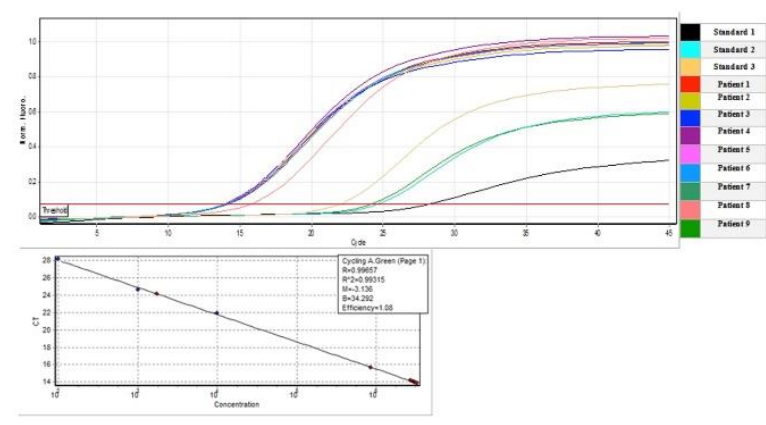

Figure 1. Viral Load Results of Nine Patient Samples and Three Standards

Viral load analysis was performed by the Real-time PCR method using a commercial kit $(\mathrm{R}=0.996$, efficiency=1.08).

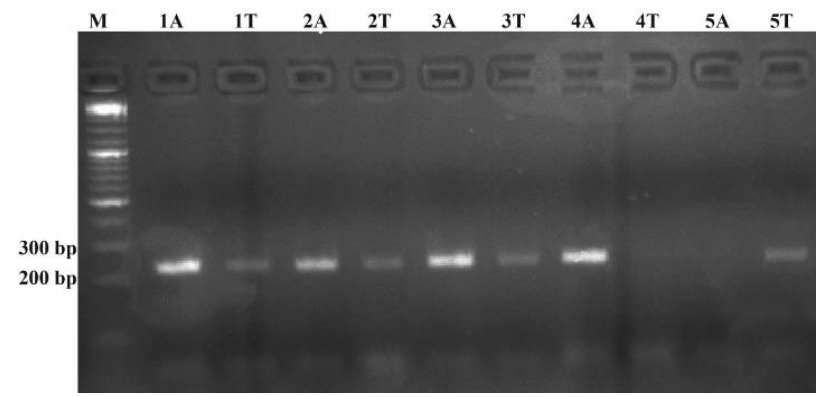

Figure 2. Agarose Gel Result of the Polymerase Chain Reaction Products of IFNG Gene +874 T/A Polymorphism

Genotype TA: sample 1 (lanes 1A and 1T), sample 2 (lanes 2A and 2T), and sample 3 (lanes 3A and 3T); genotype AA: sample 4 (lanes 4A and 4T); genotype TT: sample 1(lanes 5A and 5T), lane M: 100 bp DNA size marker

The current study suggested that the IFNG +874T/A gene polymorphism had different genotype and allele frequencies between patient and control groups. All genotypes in cases and controls were in Hardy-Weinberg Equilibrium. The frequency of the TA genotype was $62.1 \%$ in the patients, while it was $47.2 \%$ for the control group ( $\mathrm{p}=0.033$ ). The frequency of genotype AA was almost the same in both groups $(24.7 \%$ and $24.1 \%$ among control and patient groups, respectively). However, after adjusting for confounders (including alcohol consumption, drug addiction, transfusion, and tattoos), the genotypes at this position did not show any statistically significant association with $\mathrm{HCV}$ infection (adjusted P values were above 0.05). The frequency of the A allele was slightly higher in 
patients than the controls (55.2\% versus $48.3 \%$ ), while the frequency of the $\mathrm{T}$ allele was higher in controls than patients $(51.7 \%$ versus $44.8 \%$ ) (Table 2).

Based on a dominant model, carriers of the A allele were more frequent in patients with $\mathrm{HCV}$ infection compared to the control group $(55.17 \%$ in patients versus $48.31 \%$ in the controls; $\mathrm{P}=0.02$ ). However, after adjustment for confounders, the results did not remain statistically significant $(\mathrm{P}=0.2)$ (Table 3).

Table 2. Distribution of genotypes and allele frequencies of Interferon-gamma (+874) T/A single nucleotide polymorphism among control and patients groups.

\begin{tabular}{|c|c|c|c|c|c|c|c|}
\hline $\begin{array}{c}\text { IFN-Gamma } \\
\text { locus }\end{array}$ & $\begin{array}{l}\text { Control } \\
(n=89)\end{array}$ & $\begin{array}{l}\text { Frequency } \\
(\%)\end{array}$ & $\begin{array}{l}\text { Patients } \\
(n=87)\end{array}$ & $\begin{array}{c}\text { Frequency } \\
(\%)\end{array}$ & $P$ value & OR & 95\% C.I. \\
\hline \multicolumn{8}{|c|}{ Genotype Frequencies } \\
\hline TT & 25 & 28.08 & 12 & 13.79 & \multirow{2}{*}{0.02} & \multirow{2}{*}{0.41} & $(0.19-$ \\
\hline AA/AT & 64 & 71.90 & 75 & 86.21 & & & $0.87)$ \\
\hline \multicolumn{8}{|c|}{ Allele Frequencies } \\
\hline A & 86 & 48.31 & 98 & 55.17 & \multirow{2}{*}{0.02} & \multirow{2}{*}{1.31} & \multirow{2}{*}{ (0.86 1.98) } \\
\hline $\mathbf{T}$ & 92 & 51.69 & 80 & 44.83 & & & \\
\hline
\end{tabular}

Table 3. Adjusted* values for genotypes and allele frequencies of Interferon-gamma (+874) T/A single nucleotide polymorphism among control and patients groups.

\begin{tabular}{|c|c|c|c|c|c|c|c|}
\hline $\begin{array}{c}\text { IFN-Gamma } \\
\text { locus }\end{array}$ & $\begin{array}{l}\text { Control } \\
(\mathbf{n}=\mathbf{8 9})\end{array}$ & Frequency $(\%)$ & $\begin{array}{l}\text { Patients } \\
(\mathrm{n}=87)\end{array}$ & Frequency $(\%)$ & $P$ value & OR & 95\% C.I. \\
\hline \multicolumn{8}{|c|}{ Genotype Frequencies } \\
\hline $\mathbf{A A}$ & 22 & 24.72 & 21 & 24.14 & \multicolumn{3}{|c|}{ Ref } \\
\hline AT & 42 & 47.19 & 54 & 62.07 & 0.42 & 0.74 & $0.36-1.53$ \\
\hline TT & 25 & 28.09 & 12 & 13.79 & 0.14 & 1.99 & $0.80-4.95$ \\
\hline $\mathbf{A A}$ & 22 & 24.71 & 21 & 24.13 & \multirow{2}{*}{0.93} & \multirow{2}{*}{0.97} & \multirow{2}{*}{$(0.49-1.93)$} \\
\hline TT/AT & 67 & 75.27 & 66 & 75.85 & & & \\
\hline TT & 25 & 28.08 & 12 & 13.79 & \multirow{2}{*}{0.4} & \multirow{2}{*}{0.60} & \multirow{2}{*}{$(0.20-1.83)$} \\
\hline $\mathbf{A A} / \mathbf{A T}$ & 64 & 71.90 & 75 & 86.19 & & & \\
\hline \multicolumn{8}{|c|}{ Allele Frequencies } \\
\hline A & 86 & 48.31 & 98 & 55.17 & \multirow{2}{*}{0.20} & \multirow{2}{*}{1.31} & \multirow{2}{*}{$(0.86-1.98)$} \\
\hline $\mathbf{T}$ & 92 & 51.68 & 80 & 44.82 & & & \\
\hline
\end{tabular}

There was no significant association between $\mathrm{HCV}$ genotypes and $I F N G$ genotypes in patients $(\mathrm{P}>0.05)$. The study did not find any significant association between HCV RNA titer and either the $\mathrm{HCV}$ genotypes or $I F N G$ genotypes $(\mathrm{P}>0.05)$.

\section{Biochemical assay}

Biochemical results showed that mean \pm Standard Deviation (SD) of ALT levels in patients and controls were $36.42+30.59$ and $27.00+21.45$, respectively $(\mathrm{P}=0.06)$. The relationship between ALT levels (evaluated based on stratification in normal and abnormal ALT level groups) in the control and patient groups and common risk factors of HCV infection are shown in Figure 3.

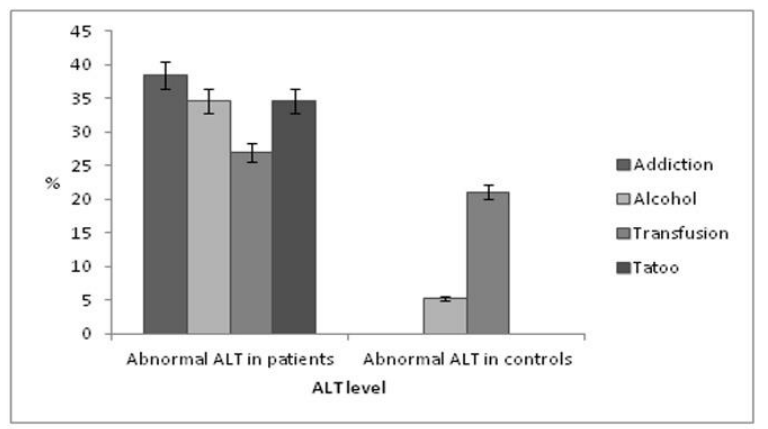

Figure 3. The Relationship between Alanine Aminotransferase Levels in the Controls and Patients and Common Risk Factors of Hepatitis C Virus Infection. ALT: alanine aminotransferase 


\section{Discussion}

The prevalence of $\mathrm{HCV}$ was shown to be below $1 \%$ in the general population of Mashhad, northeast of Iran, with genotypes 1a (41.7\%) and $3 \mathrm{a}(33.0 \%)$ being the most prevalent genotypes in this region $(24,25)$. As expected, addiction, alcohol consumption, transfusion, and tattoos had a statistically significant association $(\mathrm{p}<0.05)$ with $\mathrm{HCV}$ infection in the studied population. Although higher ALT levels were observed in the patient group (ALT (U/L), mean $\pm \mathrm{SD}=36.42+30$ ), compared to the control group (ALT (U/L, mean \pm $\mathrm{SD}=27+21.45), \quad$ a statistically significant difference was not observed for the ALT levels (pvalue $=0.06$ ). The result of genotype analysis of a dominant analysis model of the IFNG +874 T/A position (TT vs. AA+AT) indicated that the mixed $\mathrm{AA}+\mathrm{AT}$ genotype was more common in patients $(\mathrm{p}=0.02 ; \mathrm{OR}=0.41,95 \%$ CI: $0.19-0.87)$.

Viral genetic factors and variations, including different genotypes and quasi species of $\mathrm{HCV}$, and host factors including, gender, age, duration of infection, and history of alcohol intake or diabetes could influence the outcome of HCV infection (26, 27). Ethnicity has been shown to influence the inheritance of specific patterns of polymorphisms in cytokine genes (28). Polymorphisms in genes related to both adaptive and innate immunity are considered to be crucial in clearance of $\mathrm{HCV}$ infection (29).

Replication of HCV genome and the severity of the disease are known to be influenced by the expression of the $I F N G$ gene (30). Phenotypically, individuals having $\mathrm{T} / \mathrm{T}, \mathrm{T} / \mathrm{A}$, and $\mathrm{A} / \mathrm{A}$ genotypes at this position are high, intermediate, and low producers, respectively (31).

In our study, both genotype and allele frequencies at IFNG +874 T/A showed a statistically significant association with $\mathrm{HCV}$ infection $(\mathrm{p}<0.05)$. However, after adjustment for confounders (alcohol consumption, drug addiction, transfusion, and tattoos) the results did not remain statistically significant for both allele and genotype frequencies $(p>005)$. This may indicate that the observed trend in the association of some alleles and genotypes with HCV infection was not entirely dependent on the polymorphism at this position and that the confounders, which are normally associated with $\mathrm{HCV}$ infection had more profound effects.

The association of $I F N G+874 \mathrm{~T} / \mathrm{A}$ with several other infectious diseases has been studied so far. In a study from Brazil on patients with ocular toxoplasmosis and the control group (without the infection), similar to our study, after adjustment for confounders, no statistically significant difference was observed for $\mathrm{A}$ and $\mathrm{T}$ alleles ( $\mathrm{p}$-value $=0.113$ ;). In that study, however, unlike our study, which indicated an almost similar genotype frequency for AA genotype for both groups of HCV-infected patients and the control group (about 24\% genotype frequency of AA in both groups), the AA genotype was more frequent in the patient group with ocular toxoplasmosis when compared with the control group (44\% of patients vs. $23 \%$ of controls had AA) (32). With regards to other infectious diseases, a study in Turkey suggested that the TT genotype had a higher frequency in patients with brucellosis (33). In other studies, the A allele of $I F N G+874$ had also been shown to influence the outcome of diseases such as parvovirus and tuberculosis $(34,35)$.

Several studies have also noted the importance of polymorphism at $I F N G+874 \mathrm{~T} / \mathrm{A}$ with Hepatitis B Virus (HBV) infection. Among them, a study among Korean patients with HBV infection did not provide evidence in favor of the association between polymorphism at $I F N G+874 \mathrm{~T} / \mathrm{A}$ and persistent HBV infection (36). This finding was also confirmed in a study on a Turkish population, in which no association was found between $I F N G$ +874 T/A polymorphism and HBV persistence (37). A study sample of patients from North China, however, showed the association of AA genotypes with persistent infection with $\mathrm{HBV}, \mathrm{HCV}$, and HBV/HCV co-infection (38).

With regards to $\mathrm{HCV}$ infection, several studies provided evidence for the significance of this polymorphism on response to treatment and severity of the disease. A study from Taiwan on chronic HCV infected patients did not suggest any association between the inheritance of A or T allele at $I F N G+874$ and response to combination therapy with high-dose Interferon (IFN)-alpha and ribavirin (39). A similar result was also observed among Iranian patients with HCV infection, who were treated with Pegylated (PEG)-IFN plus ribavirin. In that study, no statistically significant difference was observed between allele and genotype frequencies between the responder and non-responder patients (40). The inheritance of the $\mathrm{T}$ allele at this position was considered to be associated with high rate of cirrhosis compared to carriers of homozygote A allele (p-value: 0.028) (41). Polymorphism of $I F N G$ was shown to have a role in recurrent hepatitis $\mathrm{C}$ after transplantation. It 
was shown in a study that $80 \%$ of non-recurrent patients had the polymorphism associated with higher levels of IFNG production (the T/T genotype) (42).

A study among Tunisian patients with HCV infection and a control group, similar to our study, indicated no statistically significant difference in allele or genotype frequencies between the patient and control groups at $I F N G+874(43)$.

Other SNPs have been reported in IFNG gene polymorphisms that may have more profound significance, for instance, the $-756 \mathrm{G} \mathrm{SNP}$ in the proximal IFNG promoter region was found to have more functional importance in $\mathrm{HCV}$ persistence (44), and two SNPs in IFNG R2 were found to be associated with HBV viremia. Similarly, SNPs within $I F N-A R 2$ were reported to have associations with persistent HBV infection in Gambia (45).

\section{Conclusion}

Taking into account the result of several studies, it seems that ethnicity is partly involved in susceptibility to diseases including hepatitis C virus, in which genetic polymorphisms may confer different levels of risk in different populations. Immunity is complex and many pathways, including signaling pathways are affected by the interaction of environmental and genetic factors. The difference in polymorphism of one cytokine does not directly influence the severity and the progression of a disease; it is rather the collective profile of cytokine genes, components of signaling pathways and other related genes, which determine the outcome. Even in a certain population, more accurate observations require a huge sample size representing patients with full history of therapies they have undergone, risk factors, and relevant data over a period of time. For future studies, it is preferable to use high-throughput methods of genotyping to take into account the combination of a larger number of polymorphisms in immunerelated genes and also to recruit a larger sample size of patients with a complete set of data.

\section{Acknowledgements}

This study was financially supported by Mashhad University of Medical Sciences, Mashhad, Iran (Grant No. 900513).

\section{Conflict of interests}

All authors declare no conflicts of interests.

\section{References}

1. Lavanchy D. Evolving epidemiology of hepatitis $C$ virus. Clinical Microbiology and Infection. 2011;17(2):107-15.

2. Hajarizadeh B, Grebely J, Dore GJ. Epidemiology and natural history of HCV infection. Nat Rev Gastroenterol Hepatol. 2013 09//print;10(9):553-62.

3. Kolls JK, Szabo G. The genetics of hepatitis C virus underlie its ability to escape humoral immunity. Journal of Clinical Investigation. 2015;125(1):97.

4. Brenndörfer ED, Sällberg M. Hepatitis C virusmediated modulation of cellular immunity. Archivum immunologiae et therapiae experimentalis. 2012;60(5):315-29.

5. Koziel MJ, editor Cytokines in viral hepatitis2008: () 1999 by Thieme Medical Publishers, Inc.

6. Hold GL, Untiveros P, Saunders KA, El-Omar EM. Fibrogenesis \& Tissue Repair. 2009;2(6).

7. Awad MR, El-Gamel A, Hasleton P, Turner DM, Sinnott PJ, Hutchinson IV. Genotypic variation in the transforming growth factor-[beta] 1 gene: association with transforming growth factor-[beta] 1 production, fibrotic lung disease, and graft fibrosis after lung transplantation. Transplantation. 1998;66(8):1014-20.

8. Fishman D, Faulds G, Jeffery R, Mohamed-Ali V, Yudkin JS, Humphries S, et al. The effect of novel polymorphisms in the interleukin-6 (IL-6) gene on IL-6 transcription and plasma IL-6 levels, and an association with systemic-onset juvenile chronic arthritis. Journal of Clinical Investigation. 1998;102(7):1369-76.

9. Sun Y, Lu Y, Li T, Xie L, Deng Y, Li S, et al. Interferon Gamma+ 874T/A Polymorphism Increases the Risk of Hepatitis Virus-Related Diseases: Evidence from a Meta-Analysis. PloS one. 2015;10(5):e0121168.

10. Castelli JC, Hassel BA, Wood KA, Li X-L, Amemiya K, Dalakas MC, et al. A study of the interferon antiviral mechanism: apoptosis activation by the $2-5 \mathrm{~A}$ system. The Journal of experimental medicine. 1997;186(6):967-72.

11. Goodbourn S, Didcock L, Randall R. Interferons: cell signalling, immune modulation, antiviral response and virus countermeasures. Journal of General Virology. 2000;81(10):2341-64.

12. Huang Y, Chen XC, Konduri M, Fomina N, Lu J, Jin L, et al. Mechanistic link between the anti-HCV effect of interferon gamma and control of viral replication by a ras-MAPK signaling cascade. Hepatology. 2006;43(1):81-90.

13. Carlo-Stella N, Badulli C, De Silvestri A, Bazzichi L, Martinetti M, Lorusso L, et al. A first study of cytokine genomic polymorphisms in CFS: Positive 
association of TNF-857 and IFNgamma 874 rare alleles. Clinical and experimental rheumatology. 2006;24(2):179-82.

14. Lalor PF, Shields P, Grant AJ, Adams DH. Recruitment of lymphocytes to the human liver. Immunology and cell biology. 2002;80(1):52-64.

15. Pravica V, Perrey C, Stevens A, Lee JH, Hutchinson IV. A single nucleotide polymorphism in the first intron of the human IFN- $\gamma$ gene:: Absolute correlation with a polymorphic CA microsatellite marker of high IFN- $\gamma$ production. Human immunology. 2000;61(9):863-6.

16. Makhatadze NJ. Tumor necrosis factor locus: genetic organisation and biological implications. Human immunology. 1998;59(9):571-9.

17. Smith A, Humphries SE. Cytokine and cytokine receptor gene polymorphisms and their functionality. Cytokine \& growth factor reviews. 2009;20(1):43-59.

18. Frese M, Schwärzle V, Barth K, Krieger N, Lohmann V, Mihm S, et al. Interferon- $\gamma$ inhibits replication of subgenomic and genomic hepatitis $\mathrm{C}$ virus RNAs. Hepatology. 2002;35(3):694-703.

19. Lanford RE, Guerra B, Lee H, Averett DR, Pfeiffer B, Chavez D, et al. Antiviral effect and virus-host interactions in response to alpha interferon, gamma interferon, poly (i)-poly (c), tumor necrosis factor alpha, and ribavirin in hepatitis $\mathrm{C}$ virus subgenomic replicons. Journal of virology. 2003;77(2):1092-104.

20. Napoli J, Bishop G, McCaughan G. Increased intrahepatic messenger RNA expression of interleukins 2, 6, and 8 in human cirrhosis. Gastroenterology. 1994;107(3):789-98.

21. Bonilla N, Barget N, Andrieu M, Roulot D, Letoumelin $\mathrm{P}$, Grando $\mathrm{V}$, et al. Interferon gammasecreting $\mathrm{HCV}$-specific $\mathrm{CD} 8+\mathrm{T}$ cells in the liver of patients with chronic $\mathrm{C}$ hepatitis: relation to liver fibrosis-ANRS HC EP07 study*. Journal of viral hepatitis. 2006;13(7):474-81.

22. Afshari R, Nomani H, Zaniani FR, Nabavinia MS, Mirbagheri Z, Meshkat M, et al. Genotype distribution of hepatitis $\mathrm{C}$ virus in Khorasan Razavi Province, Iran. Turkish Journal of Medical Sciences. 2014;44(4):656-60.

23. Ohno O, Mizokami M, Wu R, Saleh M, Ohba K, $\mathrm{E} \mathrm{O}$, et al. New hepatitis $\mathrm{C}$ virus (HCV) genotyping system that allows for identification of HCV genotypes 1a, 1b, 2a, 2b, 3a, 3b, 4, 5a, and 6a. J Clin Microbiol. 1997;35:201-7.

24. Shakeri MT, Nomani H, Mobarhan MG, Sima HR, Gerayli S, Shahbazi S, et al. The prevalence of hepatitis $\mathrm{C}$ virus in mashhad, iran: a population-based study. Hepatitis Monthly. 2013;13(3).

25. Afshari R, Nomani H, Zaniani FR, Nabavinia MS, Mirbagheri Z, Meshkat M, et al. Genotype distribution of hepatitis $\mathrm{C}$ virus in Khorasan Razavi
Province, Iran. Turkish Journal of Medical Sciences. 2014;44.

26. Wang X-H, Netski DM, Astemborski J, Mehta $\mathrm{SH}$, Torbenson MS, Thomas DL, et al. Progression of fibrosis during chronic hepatitis $\mathrm{C}$ is associated with rapid virus evolution. Journal of virology. 2007;81(12):6513-22.

27. Hu SX, Kyulo NL, Xia VW, Hillebrand DJ, Hu $\mathrm{K}-\mathrm{Q}$. Factors associated with hepatic fibrosis in patients with chronic hepatitis $\mathrm{C}$ : a retrospective study of a large cohort of US patients. Journal of clinical gastroenterology. 2009;43(8):758-64.

28. Hoffmann SC, Stanley EM, Cox ED, DiMercurio BS, Koziol DE, Harlan DM, et al. Ethnicity greatly influences cytokine gene polymorphism distribution. American Journal of Transplantation. 2002;2(6):560-7.

29. Lloyd AR, Jagger E, Post JJ, Crooks L-A, Rawlinson WD, Hahn YS, et al. Host and viral factors in the immunopathogenesis of primary hepatitis $\mathrm{C}$ virus infection. Immunology and cell biology. 2007;85(1):2432.

30. Lechmann M, Woitas RP, Langhans B, Kaiser R, Ihlenfeldt HG, Jung G, et al. Decreased frequency of HCV core-specific peripheral blood mononuclear cells with type 1 cytokine secretion in chronic hepatitis C. Journal of hepatology. 1999;31(6):971-8.

31. Perrey C, Pravica V, Sinnott PJ, Hutchinson IV. Genotyping for polymorphisms in interferon- $\gamma$, interleukin-10, transforming growth factor- $\beta 1$ and tumour necrosis factor- $\alpha$ genes: a technical report. Transplant Immunology. 1998;6(3):193-7.

32. Albuquerque MCd, Aleixo ALQdC, Benchimol EI, Leandro ACCS, Neves LBd, Vicente RT, et al. The IFN-3+ 874T/A gene polymorphism is associated with retinochoroiditis toxoplasmosis susceptibility. Memórias do Instituto Oswaldo Cruz. 2009;104(3):451-5.

33. Karaoglan I, Pehlivan S, Namiduru M, Pehlivan M, Kilinçarslan C, Balkan Y, et al. TNF-alpha, TGFbeta, IL-10, IL-6 and IFN-gamma gene polymorphisms as risk factors for brucellosis. New Microbiol. 2009;32(2):173-8.

34. Tso H, Ip W, Chong W, Tam C, Chiang A, Lau Y. Association of interferon gamma and interleukin 10 genes with tuberculosis in Hong Kong Chinese. Genes and Immunity. 2005;6(4):358-63.

35. Kerr J, McCoy M, Burke B, Mattey D, Pravica V, Hutchinson I. Cytokine gene polymorphisms associated with symptomatic parvovirus B19 infection. Journal of clinical pathology. 2003;56(10):725-7.

36. Cheong JY, Cho SW, Chung SG, Lee JA, Yeo $\mathrm{M}$, Wang HJ, et al. Genetic polymorphism of interferon$\gamma$, interferon- $\gamma$ receptor, and interferon regulatory factor1 genes in patients with hepatitis $B$ virus infection. Biochemical genetics. 2006;44(5-6):246-55. 
37. Karatayli S, Ulger Z, Ergul A, Keskin O, Karatayli E, Albayrak R, et al. Tumour necrosis factoralpha, interleukin-10, interferon-gamma and vitamin D receptor gene polymorphisms in patients with chronic hepatitis delta. Journal of viral hepatitis. 2014;21(4):297304.

38. Gao Q-J, Liu D-W, Zhang S-Y, Jia M, Wang L$\mathrm{M}, \mathrm{Wu} \mathrm{L}-\mathrm{H}$, et al. Polymorphisms of some cytokines and chronic hepatitis $\mathrm{B}$ and $\mathrm{C}$ virus infection. World journal of gastroenterology: WJG. 2009;15(44):5610-9.

39. Dai C-Y, Chuang W-L, Chang W-Y, Chen S-C, Lee L-P, Hsieh M-Y, et al. Polymorphisms in the interferon- $\gamma$ gene at position +874 in patients with chronic hepatitis $C$ treated with high-dose interferon- $\alpha$ and ribavirin. Antiviral research. 2005;67(2):93-7.

40. Sarvari J, Norozian H, Fattahi MR, Pirbonyeh N, Moattari A. The Role of Interferon Gamma Gene Polymorphism $(+874 \mathrm{~A} / \mathrm{T},+2109 \mathrm{~A} / \mathrm{G}$, and-183G/T) in Response to Treatment Among Hepatitis C Infected Patients in Fars Province, Southern Iran. Hepatitis Monthly. 2014;14(1).

41. Dai C-Y, Chuang W-L, Hsieh M-Y, Lee L-P, Hou N-J, Chen S-C, et al. Polymorphism of interferongamma gene at position+ 874 and clinical characteristics of chronic hepatitis C. Translational Research. 2006;148(3):128-33.
42. Ben-Ari Z, Pappo O, Druzd T, Sulkes J, Klein T, Samra Z, et al. Role of cytokine gene polymorphism and hepatic transforming growth factor $\beta 1$ expression in recurrent hepatitis $\mathrm{C}$ after liver transplantation. Cytokine. 2004;27(1):7-14.

43. Bouzgarrou N, Hassen E, Farhat K, Bahri O, Gabbouj S, Maamouri N, et al. Combined analysis of interferon- $\gamma$ and interleukin-10 gene polymorphisms and chronic hepatitis C severity. Human immunology. 2009;70(4):230-6.

44. Huang Y, Yang H, Borg BB, Su X, Rhodes SL, Yang K, et al. A functional SNP of interferon- $\gamma$ gene is important for interferon- $\alpha$-induced and spontaneous recovery from hepatitis $\mathrm{C}$ virus infection. Proceedings of the National Academy of Sciences. 2007;104(3):985-90.

45. Frodsham AJ, Zhang L, Dumpis U, Taib NAM, Best S, Durham A, et al. Class II cytokine receptor gene cluster is a major locus for hepatitis B persistence. Proceedings of the National Academy of Sciences. 2006;103(24):9148-53.

\section{How to Cite This Article:}

Rostami S, Pasdar A, Gerayli S, Hatami H, Sepahi S, Nategh F, et al. Comparison of Interferon-Gamma (IFNG) +874 T/A Single Nucleotide Polymorphism in Hepatitis C Virus Infected Patients and Non-Infected Controls in Mashhad, Iran. Iran J Pathol. 2017;12(3):248-256. 